\title{
Ceramic Art Creation from the Perspective of Senses
}

\author{
Yanming Li \\ Guangzhou Fengwo Decoration Design Co., Ltd. \\ Guangzhou, China
}

\begin{abstract}
The prevalence of the "virtualism" style makes more works focus on visual expression, and also limits the development of design creation itself. This paper attempts to explore the creation of ceramic art from the perspective of semiotics, and to carry out a comprehensive and exploratory research based on the symbolic information delivered by the consumer's visual, contact and experience. The author hopes to offer some help with designers in the design and creation, and then innovate more pottery works that have multiple sensory experiences and meet the spirit of the times.
\end{abstract}

Keywords-semiotics; ceramic art creation; transmission of information

\section{INTRODUCTION}

For a long time, the popularity of "vision only" decorative pottery creation style has led most jewelry designs to pay more attention to visual expression. Although this phenomenon has laid a solid foundation for the symbolization of pottery creation, it has limited the development of pottery art creation, making the creation of pottery arts only surface creation. With the arrival of the age of information and the global economy integration and increasing improvement of material wealth and spiritual wealth, people value the richness of the spiritual field and have a higher level of pursuit of creation, including the information conveyed by function, form, size, color, material and craftsmanship, texture, touch and hints of the heart, which shows that people not only stay at the visual level.

Consumer goods are something that can satisfy people's needs. According to people's needs, the act of buying and using products is created. Through the human sense organs, people have the feeling, acquaintance and understanding of products as well as evaluations based on cognition. This process has undergone visual and tactile sensations. Therefore, human cognition of all external things is accomplished through multiple senses. Ceramic art creation is an artistic creation of a cultural carrier. Meanwhile, it is also a manifestation of a profound symbolic language creation. It is far more from the level of "visualism".

\section{VisUAL EXPRESSION OF CERAMIC ART CREATION}

Today, the "sense" is highly valued in the era of "visual culture", so that the visual-centered visual cultural symbols have become important parts of our living environment. Ceramic art creation is no exception. The visual symbols it conveys include its color, form, texture, sound and so on. In the creation, the visual symbols it conveys will seriously affect the consumer's desire to buy and the amount of product sold.
Sense organ is not purely a tool for receiving information while the activities of sensory organs are indispensable conditions for general psychological activity. Most of the ceramic works have been seen in the form of hollowing or adding, concave and convex, and expanding to the outside and inside.

\section{THE AUDITORY EXPRESSION OF POTTERY CREATION}

The meaning of auditory language is the most abundant and accurate in semiotics. Although it is very simple, it is much disseminated. Its effect is no less than visual language and it always gives people a strong sense of presence and realism. The designers seem to inadvertently add it to the creation of ceramic art: designing the structure of some parcels, colliding objects with objects to create different sound symbolic languages and stimulate auditory, visual, and tactile appeal; or use sound language generated by the collision of different materials or between materials and patterns, making ceramic art works be added some pleasure and bringing consumers pleasure; or take actions based on the structural form to produce the sound through the collision between forms, which helps to produce a sense of staggering between reality and falseness.

Auditory language is one of the important information channels for consumers to experience products. In order to design effectively, designers must consciously or elegantly deal with the sound of ceramic art works, and perceptually process these sounds so that the sound produced by ceramic art works can convey certain information to consumers. In the practice of creation, there should be a confrontation among different potteries, pottery and others so that a variety of nice sounds will appear. In dry weather, crisp sound will appear while heavy sounds may appear in wet weather. This is the uniqueness of the auditory language after the clay material is fired, which will bring some design inspiration and space to the design.

\section{THE OLFACTORY EXPRESSION IN POTTERY CREATION}

Smell art is a very important potential expression element in art creation. The most sensitive and easiest to feel but less noticeable is the sense of smell. As an art form, it is gradually developing. Only by realizing its development in the future, can the human art of five organs be comprehensively improved and the artistic expression can be more complete. That being the case, in the creation of art, we use subtle forms to convey the sense of smell, convey the illusion of "sniffing" to 
stimulate the fantasy of the viewer, surely creating a strange and beautiful experience.

The cultural and artistic forms of the sense of smell have long been of concern in ancient times. Essence and essential oils, like Egyptian sculptures and frescoes, are part of the art that cannot be ignored in their lives. However, a lot of effort and practice must be made to achieve development through the olfactory art form in order to develop the olfactory language art form better. Therefore, paying attention to the olfactory cultural symbols of materials is an important development direction for future artistic forms. The ceramic works that are fired at different temperatures have different olfactory effects. If they are accompanied by different glaze colors and different materials to be fired, they will have other unique flavors. The selection of materials in the pottery creations allows the designer to have a multi-angle design concept that can present the olfactory language of the works in practice.

The olfactory language conveys to the audience more intimate feelings in the artistic creation but in the form of personalization. Let's recollect that when we visit someone's home, we can smell an odor, which is the owner's greeting to the guests and the unique taste. Also it informs us of the owner's lifestyle. We can see how sensitive the sense of smell is and it hides deep information. Therefore, in the creation of pottery art, it is necessary to pay attention to the cultural symbols of the sense of smell and to excavate the olfactory manifestations in its depth, especially the smelling manifestation of waste materials.

\section{The TACTILE EXPRESSION OF CERAMIC ART CREATION}

Pottery work is a viewable, wearable, touchable entity. Therefore, in addition to its visual expression and auditory effects, its tactile language also cannot be ignored. It has many other interesting texture surfaces and feelings that we can know whether it is suitable to wear and existing feeling in the heart. The most commonly used material in ceramic creation is ceramic clay. Clay is used for making pottery. It has good plasticity with yellow-brown, off-white, red-purple and other colors because it contains iron. This material, after different treatments and different combinations, will have a variety of tactile effects, such as smoothness, roughness and crudeness with slide. Clay often tends to be glazed prior to firing, which gives it a richer tactile feel. The combination of pottery clay materials and glazes with local processing will create works that give the consumer an overall sensory experience while grant it with tactile experience of gentleness, winningness, and even softness, creating a surprisingly exciting enjoyment. In addition, the designers will also embed some other materials in the creation of ceramic art to contrast with it, forming a tactile appeal to consumers.

Feeling the texture may be a wonderful process, which can make the tactile sense enjoy the wonderfulness or refinements as well as allow us to feast on the eyes. No matter what kind of effect, texture is a powerful design symbol language, and no matter what the surface texture is, it should not be arbitrary. In modern times, many designers are not limited to using only clay materials. Instead, they will consider the mix and match of materials to increase their sensory effects to enhance their value.

\section{CONCLUSION}

Ceramic art creation is the medium of symbolic language transmission. It contains a lot of space for exploration and experimentation, and the great significance and value brought about by this pioneering development have gradually emerged. The pottery creation uses the comprehensive performance of clay, glaze, and other materials to convey the actual functions and characteristics of ceramic art works through its color, form, material, and sound. It is not only an image symbol, but also a reflection of social life; it not only has cognitive function, but also has aesthetic function. The visual impact that the artwork brings to us during the creation of the designer is of course the most important factor to consider... If you are not able to visually attract your audience, you are unlikely to have the opportunity to rely on other senses to make them interested, but the sense of touch, hearing, etc. is also an important factor that cannot be ignored. Only by fully grasping the perceived part: funny colors, vivid forms, cordial touch, beautiful sounds, using sensory experiences to mobilize consumer desires can truly impress consumers.

In general, the object of sensory design is human beings and the target of product brand image design is consumers. Therefore, designers must first consider the sensory experience of consumers when designing. If the creation is involved in various sensory bodies, the integrated senses should be used as much as possible to allow the senses to coordinate with each other and unite with the products as well as pay attention to the ratio between them to achieve the best sensory experience.

\section{REFERENCES}

[1] Linghao Zhang. The semanteme of the product[M].Beijing:China Construction Industry Press, 2005.10. 张凌浩.产品的语意[M].北京: 中国建筑工业出版社, 2005.10.

[2] Xuguang Liu."Sensory aesthetics" -- how can sensory appreciation be realized[J].Zhejiang Social Sciences, 2017, 01:119-126. 刘旭光. “感官 审美”论一感官的鉴赏何以可能 [J].浙江社会科学, 2017, 01: 119-126.

[3] Runyuan Yin.Factor analysis and quality control of sensory evaluation in product design [J].Packaging engineering, 2009, 10:128-130. 殷润元 产品设计中感官评价的要素分析与质量控制[J].包装工程, 2009, 10: $128-130$.

[4] Wen Jiang,FanYu.Application Research of Sensory Evaluation Methods in Product Design Evaluation[J].Chinese Science and Technology Information, 2012,12:198-211. 姜文, 于帆.产品设计评价中感官评价 方法的应用研究[J].中国科技信息, 2012,12:198-211.

[5] Qianqian Zhang.Research on the Application of Chinese Traditional Culture in Brand Image Design under the Concept of Sensory Design [J].Mall modernization, 2015,08:30-31. 章倩倩.感官设计理念下中国 传统文化在品牌形象设计中的应用研究 [J]. 商场现代化, 2015, 08: 30-31 